\title{
EFFECT OF NOZZLE TYPE AND SOME LOCALLY USED SURFACTANTS ON THE SPRAY QUALITY
}
A. Subr*
A. Al-Ahmadi
Lecturer
Assist. Lecturer
M. Abbas
Lecturer

Dept. of Agric. Mach. and Equip., Coll. of Agric. Engin. Sci., University of Baghdad alaa.kamel@coagri.uobaghdad.edu.iq

\section{ABSTRACT}

This study was aimed to compare two spreading agents (Tween 20 (T) and dishwashing detergent (D)) which are commonly used in agricultural researches in Iraq and sometimes are used by the local spray applicators. Moreover, the universalflat fan nozzle (UNI) was compared with the air induction nozzle (AI) concerning the quality of the spray produced. The treatments included three concentrations $(1.0 \% ; 0.1 \%$ and $0.01 \%$ vol $/ \mathrm{vol} \%)$ of each spreading material beside the control treatment (water only). Spray quality was evaluated by using the water sensitive papers (WSP), and DepositScan software was used to analyze the scanned photos of WSP. Theevaluated parameters related to the spray quality included: spray coverage (\%); spray density (Deposits/cm²); average droplet diameter (DV.5) and deposition of droplets $\left(\mu \mathrm{L} / \mathrm{cm}^{2}\right)$. Moreover, the penetration rate was also calculated by comparing the deposition quantity between two levels of WSP on the plant canopy (upper and middle level) while the deposition which reached the ground was considered as losses rate. The results have shown that adding Tween 20 spreading agent to the spray solution has produced more deposits per square centimeter and more penetration rate of spray inside the plants canopy than the detergent and control. Moreover, the UNI type nozzle produced higher coverage percentage and number of deposits per square centimeter than AI nozzle.

Key words: surface tension; detergent; air induction nozzles; flat fan nozzles; spray density

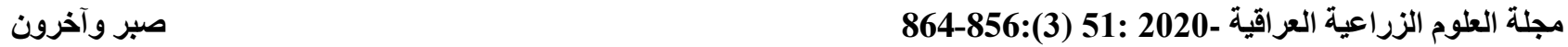

تأثير نوع النافورة ويعض المواد الناشرة للرذاذ المستخدمة محليا في نوعية الرذاذ المترسبة

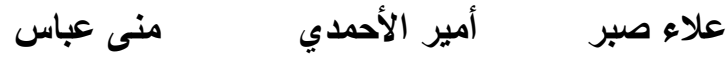

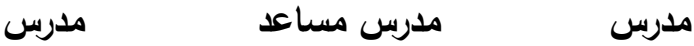

$$
\begin{aligned}
& \text { قسم المكائن والآلات الزراعية، كلية علوم الزهدسة الزراعية، جامعة بغداد، العراق }
\end{aligned}
$$

المستخلص

كان الغرض من هذا البحث هو مقارنة مادتين ناشرتين يستخدمان بشكل شائع في الأبحاث الزراعية في العراق وأحيانًا يتم

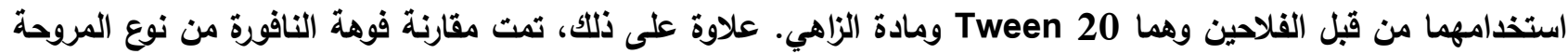
المسطحة التقليدية (UNI) بفوهة النافورة من نوع سحب الهواء (AI) فيما يتعلق بجودة الرش المنتج. تضمنت المعاملات استخدام ثلاث تراكيز حجمية لكل مادة ناشرة هي: 1.0٪ و 0.1\% و 0.01\% بجانب معاملة التحكم (الماء فقط). تم تقييم جودة الرش باستخدام الأولق الحساسة للمياه (WSP) وتم استخدام برنامج DepositScan لتحليل الصور الممسوحة

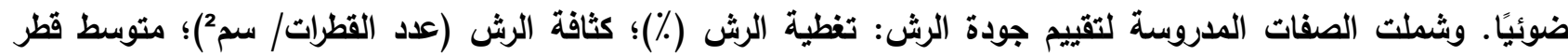
القطراتوكمية القطرات المترسبة (ميكرولتر/ سم2). علاوة على ذلك، تم حساب معدل الاختراق أيضًا من خلال مقارنة كمية الترسب بين مستويين من WSP على هيكل النبات (المستوى العلوي والمتوسط) بينما اعتبر الترسب الذي وصل إلى مستوى الأرض كمعدل لخسائر الرذاذ. أظهرت النتائج أن إضافة المادة الناشرة Tween 20 إلى محلول الرش قد أدى إلى ظهور كثافة اكبر للقطرات لكل سنتيمتر مربع ومعدل اختراق أكبر للرذاذ داخل هيكل النباتات مقارنة مع معاملة الزاهي ومعاملة المقارنة.

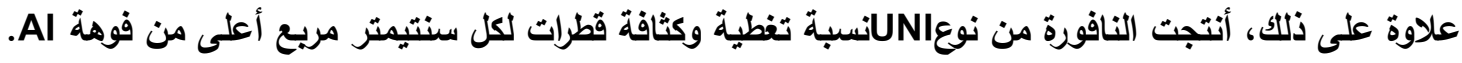

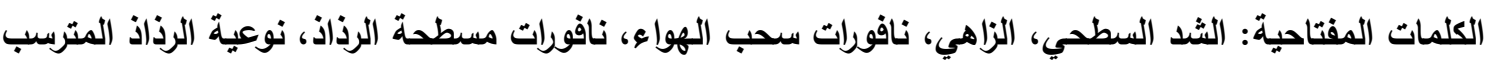

*Received:1/6/2019, Accepted:17/9/2019 


\section{INTRODUCTION}

Using the nonionic surfactant Tween 20 (polyoxyethylene (20) sorbitan monolaurate) is popular in agricultural crop spraying studies that include field and laboratory researches because of its stability and relative nontoxicity (15). The nonionic surfactant polysorbate 20 (known by its tradename as Tween 20) is usually used in agriculture, agrochemical formulations and pesticide application researches because it imitates the application as in real conditions $(6,17)$. Nuyttens et al. (16) indicated that after adding $0.1 \%$ of Tween 20 to water, the solution properties became the same as this for the plant protection products such as surface tension of $47.9 \pm 0.6 \mathrm{mN} \mathrm{m}^{-1}$, a liquid density of $1.01 \pm 0.02 \mathrm{~kg} \cdot \mathrm{l}^{-1}$, and a relative extensional viscosity of $1.01 \pm 0.01$. Macisaac et al. (12) reported an increase in the uptake of glyphosate IPAS after adding Tween 20 comparing with using glyphosate alone. Applying Tween 20 with tap water by using nozzle types XR8001vk - XR8003vk at 2.0 and 3.0 bar pressure resulted in no differences in VMD (Volume Median Diameter) values. However, finer drops were observed in the spray produced from coarser nozzles types (XR8004vk, XR8005vk, XR8006vk, XR8008vk) after adding Tween 20 to the tap water comparing with using water alone (8). Wang et al. (19) results showed that adding Tween 20 to polyethylene oxide (PEO) solution caused a significant decrease in the Dv0.5 values and caused an increase in the percentage of the fine drops. Dorr et al. (7) indicated that the shatter of drops increased as the drop size and velocity increased and also the bouncing of drops happened frequently on the hard to moisturizetargets and when applying spray which has a high value of surface tension (water for example). Lowering the value of surface tension by adding adjuvants (surfactants) will enhance the initial adhesion but will cause more shatter of drops due to the decrease in the surface energy which in turn will make the drops tending to break-up. AI nozzles have a larger orifice area (at least 2.1 larger) than XR nozzles when both types of nozzles have the same nominal flow rate, and that is why the AI nozzles produce larger size drops. However, there were no significant differences between AI and XR nozzles concerning drop sizes, spray swath, spray coverage, and drift reduction potential when AI and XR have the same orifice size and flow rate (work with different spraying pressure) (9).The WSP was studied and used by many researchers, it is used to characterize the spray quality after it will deposit on the target $(15 ; 18 ; 21 ; 22 ; 23)$. Marçal and Cunha (14) results indicated that, with an appropriate scanning resolution, the water sensitive paper (WSP) could provide good results of coverage homogeneity and the factors of stains size spectra.Many Iraqi researchers used detergent liquid as a spreading material instead of Tween 20 (wetting agent) to assist the spreading of the sprayed liquid on the target. An example of those researches is: (3) (powder detergent, 1-2 g. $1^{-1}$ concentration); (1); (2); (4) (0.1\% concentration); (5). However, some researchers use Tween 20 as a spreading material for example: (10) (concentration: 2-3 drops/l); (11); (13) (concentration: $15 \mathrm{~cm}^{3}$ of Tween 20 for 100 literof water). The aim of this research is to study the effect of two types of locally used surfactants on the spray quality and find out whether the Detergent from the local market can be used as an alternative of Tween 20 which is more expensive and difficult to offer (for the operators in villages). Moreover, comparing the conventional nozzle UNI with AI nozzle concerning their effect on the spray quality when they work with those surfactants.

\section{MATERIALS AND METHODS}

\section{Surfactants}

Two locally used surfactants were used in this research, the first was Tween 20 (Merck, Germany) which is a nonionic surfactant and the second was a dishwashing detergent liquid (Pril - HenkelAG \& Company, KGaA, Germany) typically used in the spraying researches. The ingredients for the detergent were: non-ionic surfactants $15-30 \%$, Amphotericsurfactants. Three volumetric concentrations of Tween 20 and the detergent were included in the study, and the prepared solutions were:

- Water as control (C)

- $1.0 \% ; 0.1 \%$ and $0.01 \%$ vol $/ \mathrm{vol} \%$ of Tween

$20+$ water $(\mathrm{T})$

- $1.0 \% ; 0.1 \%$ and $0.01 \%$ vol $/$ vol $\%$ of Detergent + water (D) 
The spray liquid was prepared and consisted of a solution of the surfactants of each concentration after mixing with water.The surface tension measurement was done using Wilhelmy plate method $(0.1 \mathrm{ml}$ sample $)$ with a Surface Tensiometer SIGMA 70 series (KSV Instruments LTD, Finland) device in the laboratory of Ministry of Science and Technology - Baghdad at room temperature of $20^{\circ} \mathrm{C}$, the results are listed in Table 1 .

\section{Nozzles, sprayer and spraying}

Two types of nozzles were used in this research, Agroplast universal flat fan nozzle 12003 (UNI) and Agroplast Air-induction flat fan nozzle 8MS 03 (AI). Knapsack sprayer with 16-liter tank was used to spray the liquid, the sprayer has a battery to supply the power to the pump which provides a pressure range 0 -4 bar. The sprayer lance equipped with a pressure gauge to indicate the spraying pressure during work (Figure 1).

Table 1. The surface tension of the surfactants with different concentration

\begin{tabular}{|lcc|}
\hline Spreadin & $\begin{array}{c}\text { Concentration, } \\
\text { vol /vol \% }\end{array}$ & $\begin{array}{c}\text { Surface } \\
\text { tension, }\end{array}$ \\
material & & 2 \\
Tween 20 & 0.01 & 30.8 \\
& 0.05 & 28.3 \\
& 0.1 & 27.95 \\
& 0.5 & 27.09 \\
Detergent & 1.0 & 26.66 \\
& 0.01 & 36.47 \\
& 0.05 & 28.23 \\
& 0.1 & 26.95 \\
& 0.5 & 23.18 \\
\hline
\end{tabular}

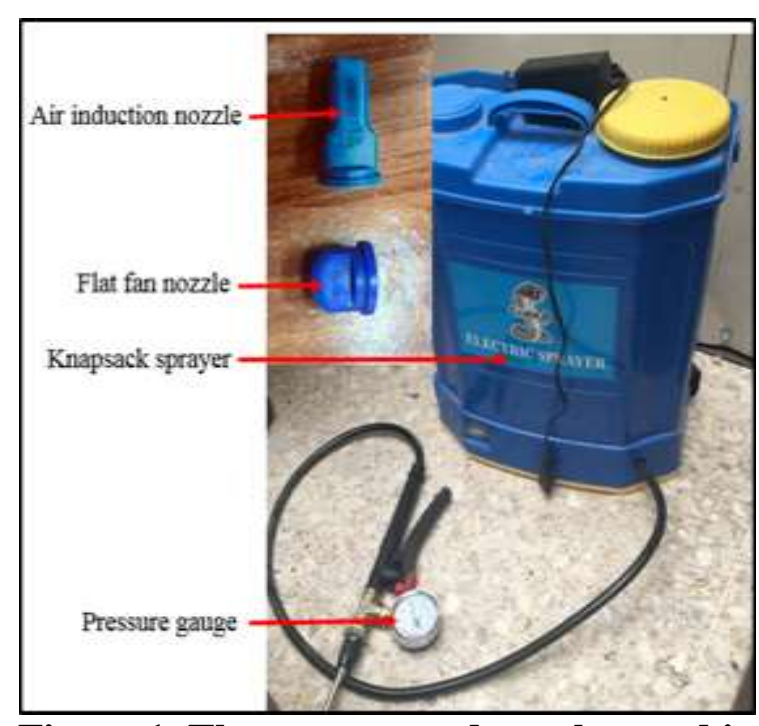

Figure 1. The sprayer and nozzles used in the research
The sprayer calibration using water was done prior to the application of the surfactants. This included measuring the flow rate of each nozzle type, the operator average speed during spraying, and the spray swath. The application rate was adjusted at $284 \mathrm{1} / \mathrm{ha}$ for all of the treatments by fixing the flow rate, spraying speed, and spray swath during the experiment (Table 2).

Table 2. Spraying parameters for the nozzles and sprayer during the test.

\begin{tabular}{|ll|}
\hline Spraying parameter & Value \\
\hline Flow rate & $1.2 \mathrm{l} / \mathrm{min}$ \\
Spraying speed & $3.0 \mathrm{~km} / \mathrm{h}$ \\
Spraying pressure & $\mathbf{3 . 0} \mathrm{bar}$ \\
Spray swath & $120 \mathrm{~cm}$ \\
Distance between $\quad$ nozzle and & $\mathbf{5 0} \mathrm{cm}$ \\
plants & \\
Application rate & $\mathbf{2 8 4} \mathrm{l} / \mathrm{ha}$ \\
\hline
\end{tabular}

The spraying was done on January 2019 in a greenhouse planted with eggplant (Solanum melongena), it was a special strain on the national program for the production of domestic vegetable crops and strains, and the planting date was on September 2018. The greenhouseis located in the experimental station of the Horticulture office - Ministry of Agriculture - Baghdad. The area of the greenhouse was $500 \mathrm{~m}^{2}$ and has five rows, the space between rows $70 \mathrm{~cm}$. The plants were on $50 \mathrm{~m}$ long rows, the width of the row was 80 $\mathrm{cm}$ and the space between plants on the row was $80 \mathrm{~cm}$. The number of plants on the greenhouse was 625 plants, the height of plants during spraying was $50-70 \mathrm{~cm}$.

\section{WSP setting and analyzing}

The target for collecting the spray deposit was the water sensitive papers $(76 \times 26 \mathrm{~mm}$, TeeJet technologies, Wheaton, USA) which their yellow color surface turn to blue after getting in contact with the moisture or droplet of a liquid. Iron poles (Figure 2) were distributed randomly inside the canopy of plants in the plots. The poles have three levels of rectangular surfaces to fix the WSP on it. The first surface height from the ground was $5 \mathrm{~cm}$ which represents the lowerlevel (LO), the second was $25 \mathrm{~cm}$ which represent the middle level (MI) and the third was $45 \mathrm{~cm}$ which represent the upper level (UP). The WSPs were carefully fixed on their places prior to the spraying of each treatment, and the sprayer work was tested for a few seconds before entering the plot. After spraying the liquid, the 
WSPs were collected and left on a table for a few minutes to dry and then were put inside an envelope for further evaluation. A printer scanner (Brother MFC J480DW) was used to scan photos for the WSPs with $600 \mathrm{dpi}$ resolution. After this,

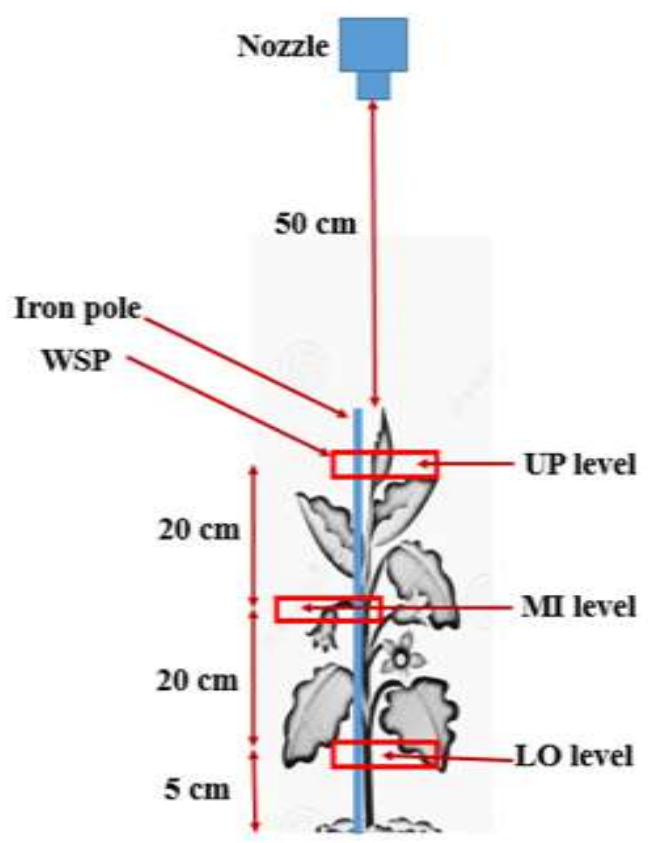

Figure 2. The setting of WSP on the plant canopy

a software "DepositScan" (Portable Scanning System for Spray Deposit Qualification) (20) was used to calculate:

1- The coverage percentage (Coverage, \%) within the selected area, it represents the percentage of the WSP area covered with the blue stains to the yellow background area

2- Average diameter or Volume Median Diameter (DV.5) which represents the distribution of the droplet diameters such that droplets with a diameter smaller than DV.5 compose $50 \%$ of the total liquid volume

3- Stains density (Deposits $/ \mathrm{cm}^{2}$ ) which represents the number of stains on the square centimeter

4- Deposition quantity $\left(\mu \mathrm{L} / \mathrm{cm}^{2}\right)$ which represents the volume deposited on the square centimeter

Moreover, the penetration rate was calculated as a ratio between the deposits mean on the middle sensitive papers and the summation of the deposits means on the upper, middle, and lower sensitive papers.

Where:

$$
P R=\frac{D_{M I}}{D_{U P}+D_{M I}+D_{L O}}
$$

Where:

$P R$ :the penetration rate.

$D_{U P}$ :the deposits mean on the upper WSP

$D_{M I}$ :the deposits mean on the middleWSP.

$D_{L O}$ :the deposits mean on the lowerWSP.

The losses rate was similarly calculated using the deposits mean on the lower sensitive papers at the numerator instead of the mean on the middle sensitive papers.

$$
L=\frac{D_{L O}}{D_{U P}+D_{M I}+D_{L O}}
$$

L:the spray losses.

$D_{U P}$ :the deposits mean on the upperWSP.

$D_{M I}$ :the deposits mean on the middleWSP.

$D_{L O}$ :the deposits mean on the lowerWSP

Each image spot area was converted by the software to the actual droplet diameter using the equation (20):

$$
{ }_{\text {Data analysis }}^{\mathrm{Dd}}=1.06 \mathrm{As}{ }^{0.455}
$$

The statistical analyses were performed using OriginPro,b9.5.1.195.OriginLab Corporation, Northampton, MA, USA

Two-way ANOVA and one-way ANOVA were used to analyze the data of each of the four variables (DV.5, coverage percentage, spray density (deposits.cm ${ }^{-1}$ ), and deposition $\mu \mathrm{L} / \mathrm{cm}^{2}$ ). First, two-way ANOVA was performed considering the nozzle type with two levels (AI and UNI) and the surfactant with three levels (control, detergent, and Tween 20) as independent variables to investigate the effect of nozzle type, and the surfactant added on the studied variables. Second, one-way ANOVA and Fisher's least significant-difference test at $95 \%$ confidence level were performed considering the concentration of a surfactant as an independent variable grouping analysis by the nozzle type and the surfactant to investigate the effect of the concentration for each surfactant on the studied variables.

\section{RESULTS AND DISCUSSION}

DV.5 (mm): Bigger droplet size (bigger DV.5 values) is better for reducing drift risk. However, it could affect the coverage percentage because bigger droplets size produces smaller coverage percentage.The two-way ANOVA showed that there was a highly significant difference $(\mathrm{F}(1,118), \mathrm{p}<$ 0.0001 ) between the two nozzle types where the AI type exceeded the UNI type in 
producing bigger size droplets (Table 3)and this result agreed with $(24 ; 25)$. This is probably because the air-filled droplets produced by AI nozzlesleadto bigger size. There were no significant differences among the surfactant types $(F(2,118), p=0.6505)$.

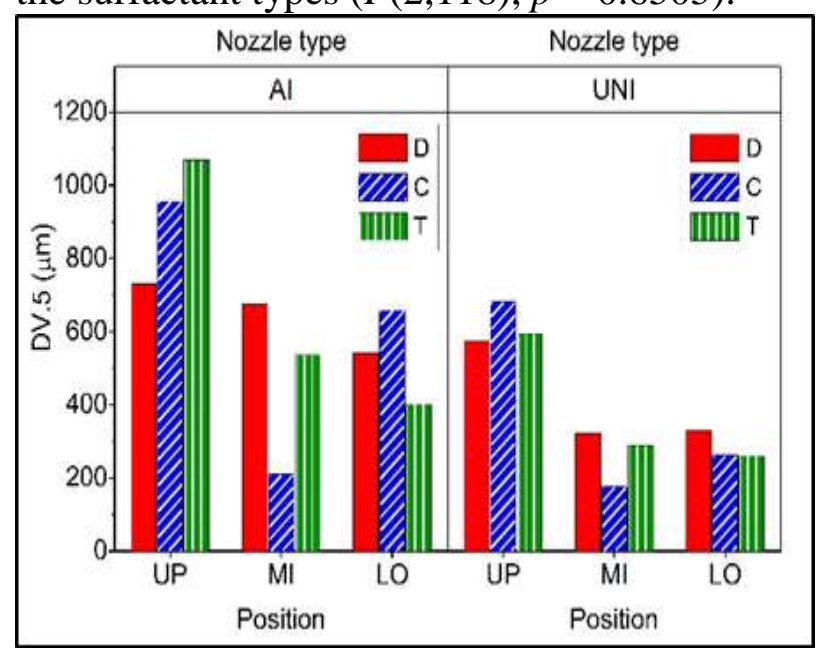

Figure 3. DV.5 results for the interaction between nozzle types and surfactant in the three levels of WSP

This is probably because there were small differences in the surface tension values *(Table 1) among the surfactant type. The oneway ANOVA showed that there were no significant differences among the levels of concentrations of any surfactant.

Table 3 . Effect of nozzle type and surfactant and their interactions on the DV.5.

\begin{tabular}{|ccc|}
\hline $\begin{array}{c}\text { Level of } \\
\text { Nozzle type }\end{array}$ & $\begin{array}{c}\text { Level of } \\
\text { Spreading agent }\end{array}$ & $\begin{array}{c}\text { DV.5 }(\mu \mathrm{m}) \\
\text { Mean* }\end{array}$ \\
\hline AI & T & $668.81 \mathrm{a}$ \\
AI & D & $649.07 \mathrm{ab}$ \\
AI & C & $607.89 \mathrm{abc}$ \\
UNI & D & $407.96 \mathrm{~b}$ \\
UNI & T & $381.22 \mathrm{bc}$ \\
UNI & C & $284.43 \mathrm{abc}$ \\
Effect of nozzle type & & \\
AI & & $651.65 \mathrm{a}$ \\
UNI & & $381.95 \mathrm{~b}$ \\
Effect of spreading material type & \\
C & & $466.38 \mathrm{a}$ \\
D & & $528.52 \mathrm{a}$ \\
T & & $525.02 \mathrm{a}$ \\
\hline
\end{tabular}

*Means within a row followed by the same letter are not significantly different at the $5 \%$ level as measured by the LSD test
Results for the DV.5 on the three levels of the WSP inside the plant canopy are presented in Figure 3. The interaction between the nozzle type and the surfactant indicated that at the upper level, the AI nozzle and the Tween 20 surfactant produced numerically but not significantly bigger droplet diameters than other interactions, while the UNI nozzle and the detergent resulted in the smallest droplet size.

Coverage (\%)

Higher values of coverage percentage are required to get better biological control especially when using contact pesticide. There was a highly significant difference $(F(1,118)$, $p<0.0011)$ between the two nozzle types where the UNI type produced a higher percentage of coverage than the AI type (Table 4). This could be as a result of the fine droplet produced by UNI nozzle as mentioned in the DV.5 results previously.

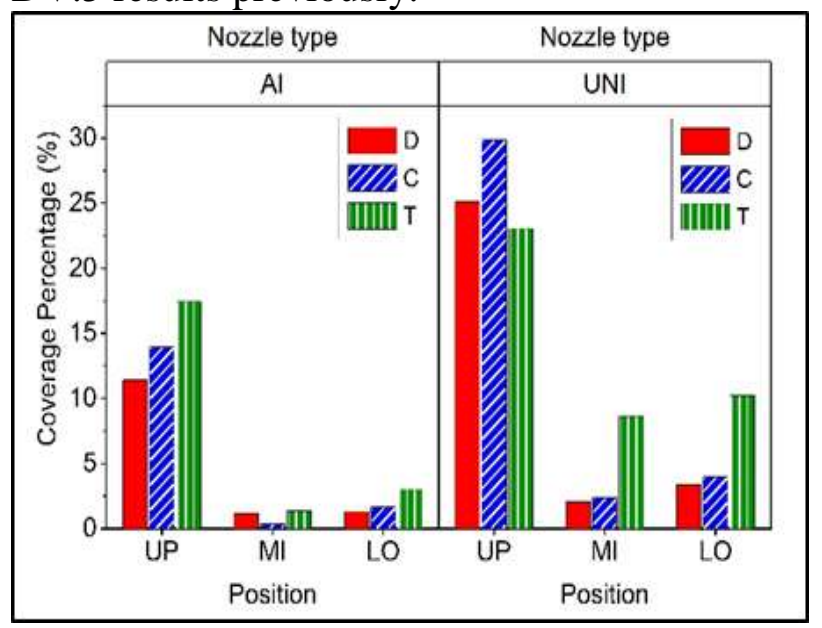

Figure 4. Coverage percentagefor the interaction between nozzle types and surfactant in the three levels of WSP

There were no significant differences among the surfactant types $(F(2,118), p=0.1228)$ concerning the coverage percentage on the WSP, this could be due to the results of the droplet size (DV.5 ) produces from both of the surfactant types (there were no differences in the droplet size). According to the one-way ANOVA, there were no significant differences among the levels of concentrations of any surfactant. 
Table 4. Effect of nozzle type and surfactant and their interactions on the coverage percentage.

\begin{tabular}{|ccc|}
\hline $\begin{array}{c}\text { Level of } \\
\text { Nozzle type }\end{array}$ & $\begin{array}{c}\text { Level of } \\
\text { Spreading agent }\end{array}$ & $\begin{array}{c}\text { Coverage (\%) } \\
\text { Mean* }\end{array}$ \\
\hline UNI & T & $13.97 \mathrm{ab}$ \\
UNI & D & $10.17 \mathrm{a}$ \\
AI & T & $7.27 \mathrm{ab}$ \\
UNI & C & $6.97 \mathrm{ab}$ \\
AI & $\mathrm{C}$ & $5.29 \mathrm{ab}$ \\
AI & D & $4.61 \mathrm{~b}$ \\
Effect of nozzle type & & \\
AI & & $5.85 \mathrm{~b}$ \\
UNI & & $11.49 \mathrm{a}$ \\
Effect of spreading material type & \\
C & & $6.03 \mathrm{a}$ \\
D & & $7.39 \mathrm{a}$ \\
T & & $10.62 \mathrm{a}$ \\
\hline
\end{tabular}

*Means within a row followed by the same letter are not significantly different at the $5 \%$ level as measured by the LSD test.

Spraying using UNI nozzle produced higher coverage percentage in the upper level of WSP comparing with AI nozzles (Figure 4), the same trend was observed in both middle and lowerlevels.

\section{Stains density (Deposits $/ \mathrm{cm}^{2}$ )}

Higher values of spray density (Deposits $/ \mathrm{cm}^{2}$ ) give an indicator of better coverage percentage beside it could be an indicator of better distribution of stains on the target surface. A highly significant difference $(F(1,118), \quad p<$ $0.0001)$ between the two nozzle types where spraying with UNI type nozzle had more spray density (number of deposits on the square centimeter) than the AI type (Table 5). This is because spraying the same spray volume but with smaller drops size will result in higher number of droplets on a specific area.

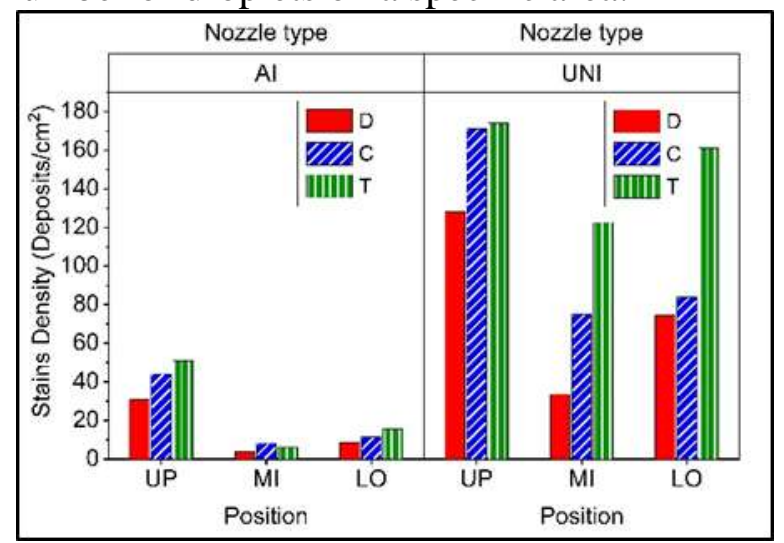

Figure 5. Spray density $\left(\operatorname{deposits} / \mathrm{cm}^{2}\right)$ results for the interaction between nozzle types and surfactant in the three levels of WSP
Highly significant differences were observed among the surfactant $(F(2,118), p<0.0001)$ where the Tween surfactant significantly exceeded the Detergent and Control, whereas there was no significant difference between the Detergent and the Control. The one-way ANOVA showed that there were no significant differences among levels of concentrations of any surfactant.

Table 5. Effect of nozzle type and surfactant and their interactions on deposits $/ \mathrm{cm}^{2}$.

\begin{tabular}{|ccc|}
\hline $\begin{array}{c}\text { Level of } \\
\text { Nozzle } \\
\text { type }\end{array}$ & $\begin{array}{c}\text { Level of } \\
\text { Spreading } \\
\text { agent }\end{array}$ & $\begin{array}{c}\text { Deposits/cm } \\
\text { Mean* }\end{array}$ \\
\hline AI & C & $21.26 \mathrm{c}$ \\
AI & D & $14.27 \mathrm{c}$ \\
AI & T & $24.21 \mathrm{c}$ \\
UNI & C & $92.46 \mathrm{~b}$ \\
UNI & D & $78.67 \mathrm{~b}$ \\
UNI & T & $152.44 \mathrm{a}$ \\
Effect of nozzle type & \\
AI & & $19.53 \mathrm{~b}$ \\
UNI & & $112.90 \mathrm{a}$ \\
Effect of spreading material type & \\
C & & $52.41 \mathrm{~b}$ \\
D & & $46.47 \mathrm{~b}$ \\
T & & $88.32 \mathrm{a}$ \\
\hline
\end{tabular}

*Means within a row followed by the same letter are not significantly different at the $5 \%$ level as measured by the LSD test.

The same results of the coverage percentage were observed concerning the spray density (number of deposits on the square centimeter) in the three levels of WSP as Figure 5 shows. Moreover, using the surfactant Tween 20 produced higher density of droplets than using Detergent or Control especially using UNI nozzle in the upper level of WSP.

Deposition quantity $\left(\boldsymbol{\mu L} / \mathrm{cm}^{2}\right)$

The results of the analyses showed that there was no significant difference between the two types of the nozzle nor among the three levels of surfactant (Table 6). 


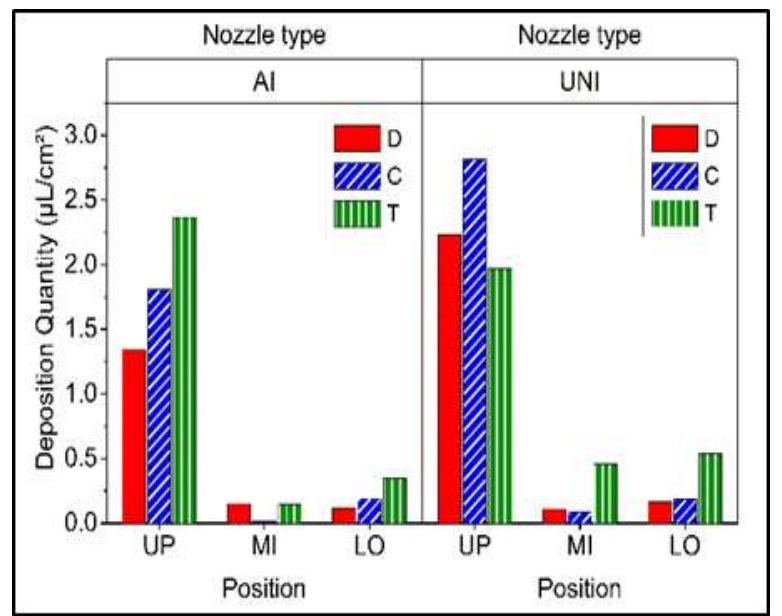

Figure 6. Deposition results for the interaction between nozzle types and surfactant in the three levels of WSP

This is probably come from that the same amount of spray (the same application rate 1/ha) was applied for all the treatments. There were no significant differences among levels of concentrations of any surfactant.

Table 6. Effect of nozzle type and surfactant and their interactions on the deposition $\left(\mu \mathrm{L} / \mathrm{cm}^{2}\right)$.

\begin{tabular}{|ccc|}
\hline $\begin{array}{c}\text { Level of } \\
\text { Nozzle } \\
\text { type }\end{array}$ & $\begin{array}{c}\text { Level of } \\
\text { Spreading } \\
\text { agent }\end{array}$ & $\begin{array}{c}\text { Deposition } \\
\left(\mu \mathrm{L} / \mathrm{cm}^{2}\right) \\
\text { Mean* }\end{array}$ \\
\hline AI & $\mathrm{C}$ & $0.67 \mathrm{a}$ \\
AI & $\mathrm{D}$ & $0.54 \mathrm{a}$ \\
AI & $\mathrm{T}$ & $0.95 \mathrm{a}$ \\
UNI & $\mathrm{C}$ & $0.52 \mathrm{a}$ \\
UNI & $\mathrm{D}$ & $0.83 \mathrm{a}$ \\
UNI & $\mathrm{T}$ & $0.99 \mathrm{a}$ \\
Effect of nozzle type & \\
AI & & $0.73 \mathrm{a}$ \\
UNI & & $0.87 \mathrm{a}$ \\
Effect of spreading material type & \\
C & & $0.60 \mathrm{a}$ \\
D & & $0.69 \mathrm{a}$ \\
T & & $0.97 \mathrm{a}$ \\
\hline
\end{tabular}

*Means within a row followed by the same letter are not significantly different at the $5 \%$ level as measured by the LSD test.

Deposition results (Figure 6) showed that the upper level of WSP had received the highest percentage of spray volume. Spraying water using UNI nozzle produced the highest value of deposition on the upper level while the AI nozzle and detergent combination had the lowest values. Depending on the results of the deposition, the penetration rates were $6 \%$ and
$10 \%$ for the AI and UNI nozzle type respectively (Figure 7), while they were 6\%, $10 \%$, and $2 \%$ for the Detergent, Tween, and the Control, respectively. The losses rates for UNI nozzles were $12 \%$ which is higher than this for AI nozzles (10\%), and it was 7\%, 15\% and $8 \%$ for the Detergent, Tween, and the Control respectively.

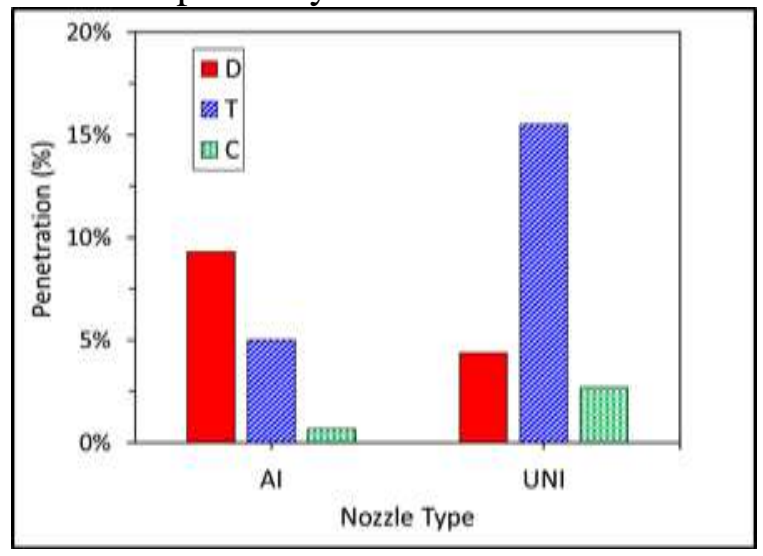

Figure 7. the penetration rates' results for the nozzle types and surfactants

\section{CONCLUSION}

Depending on the circumstances and the results of the experiment we can conclude the following:

1- There was no preference among the Control, Detergent, and Tween 20 in relation to the DV.5 and the coverage, whereas the Tween 20 was better than the Detergent and Control in relation to the deposits per square centimeter.The spray penetration rate from the upper level of the plant canopy to the middle level was higher when using Tween 20 as a spreading agent.

2- This experiment also showed that there was no effect of the concentration of the surfactant on any of the studied variables

3- The AI nozzle had a bigger droplet diameter (DV.5) than UNI, whereas the UNI type produced higher coverage percentage and number of deposits per square centimeter than AI type. Moreover, spraying with UNI nozzle also produced a higher penetration rate of spray. However, this higher penetration rate of UNI nozzle was accompanied with higher losses rate of spray which penetrate to the level which is near the ground (lowerlevel).

\section{ACKNOWLEDGEMENT}

The authors would like to thank the Horticulture office in the Ministry of Agriculture and Mr. Tahseen Alshujiri for their useful suggestions and help. 


\section{REFERENCES}

1. Abood, N.M. and M.A. Salh, 2018. Response of several sorghum varieties to potassium foliar. The Iraqi Journal of Agricultural Science, 49(6): 973

2. Abood, N.M., H.K. Khrbeet, and A.K. Saleh, 2017. Effect of foliar application of nitrogen on grain yield and it's component in sorghum. The Iraqi Journal of Agricultural Science, 48(3): 740

3. Al-Atrushy, S.M., 2019. Effect of foliar application of micronutrients and canopy management on yield and quality of grapevine (VitisvinferaL) cv. Mirane. Iraqi Journal of Agricultural Sciences, 2(50

4. Al-Hayany, A.A., E.M. Al-Sarah, and N.M. Hathal, 2017. Effect of foliar application salicylic acid on citrus rootstocks tolerance to soil salinity. The Iraqi Journal of Agricultural Science, 48(3): 707

5. Al-Naqeeb, M.A. and M.A. Hashim, 2017. Effect of ethephon concentration at different growth stages on yield and its components of wheat. The Iraqi Journal of Agricultural Science, 48(2): 563

6. Bai, G., K. Nakano, T. Mizukami, S. Miyahara, S. Ohashi, Y. Kubota, K.I. Takizawa, and H. Yan, 2013. Characteristics and classification of Japanese nozzles based on relative spray drift potential. Crop protection, 46: 88-93

7. Crowe, T. G., D. Downey, and D. K. Giles. 2005. Digital device and technique for sensing distribution of spray deposition. Trans. ASAE 48 (6): 2085-2093

8. Dorr, G.J., A.J. Hewitt, S.W. Adkins, J. Hanan, H. Zhang, and B.Noller, 2013. A comparison of initial spray characteristics produced by agricultural nozzles. Crop Protection, 53: 109-117

9. Dorr, G.J., S. Wang, L.C. Mayo, S.W. McCue, W.A. Forster, J. Hanan, and X. He, 2015. Impaction of spray droplets on leaves: influence of formulation and leaf character on shatter, bounce and adhesion. Experiments in Fluids, 56(7): 143

10. Focus 2007. Landscape and mitigation factors in aquatic risk assessment. Volume 2. Detailed technical reviews. Report of the Focus working group on landscape and mitigation factors in ecological risk assessment, EC document reference 5(20): 436
11. Fox, R. D., R. C. Derksen, J. A. Cooper, C. R. Krause, and H. E. Ozkan. 2003. Visual and image system measurement of spraydeposits using water - sensitive paper. Applied Eng. in Agric.19 (5): 549-552

12. Guler, H., H. Zhu, H.E. Ozkan, R.C. Derksen, Y. Yu, and C.R. Krause, 2007. Spray characteristics and drift reduction potential with air induction and conventional flat-fan nozzles. Transactions of the ASABE, 50(3): 745-754

13. Hedo E. K., 2011. Effect of spraying some foliar fertilizers on growth and yield of green pods of cowpea plant Vigna Sinensis L. AlTaqani journal. 24 (1): 242-249

14. Heinkel, R., A. Fried, and E. Lange. 2000. The effect of air injector nozzles on crop penetration and biological performance of fruit sprayers. Aspects Appl. Biol. 57: 301-307

15. Huthily K.H., M. M. Almukhtar and A. S. Al-Ansary, 2007. Effect of application methods of iron on nitrogen fixation efficiency in alfalfa (Medicago sativa L.). Basrah Journal of Science. 25 (18): 44-58.

16. Macisaac, S.A., R.N. Paul, and M.D. Devine, 1991. A scanning electron microscope study of glyphosate deposits in relation to foliar uptake. Pesticide Science, 31(1): 53-64

17. Manaa A. A., 2010. Effect of two types of foliar fertilizers in the growth and yield of two varieties of solanum tuberosum. Euphrates Journal of Agriculture Science. 2 (2): 60-67.

18. Marçal, A.R.S. and M. Cunha, 2008. Image processing of artificial targets for automatic evaluation of spray quality. Transactions of the ASABE, 51(3): 811-821.

19. Nuyttens, D., M. De Schampheleire, K. Baetens, and B. Sonck, 2007. The influence of operator-controlled variables on spray drift from field crop sprayers. Transactions of the ASABE, 50(4): 1129-1140

20. Ozkan, H. E., P. A. Paul, R. C. Derksen, and H. Zhu. 2012. Influence of application equipment on deposition of spray droplets in wheat canopy. International Advances in Pesticide Applications - Aspects of Applied Biology, 114: 317-324

21. Panneton, B. 2002. Image analysis of water -sensitive cards for spray coverage experiments. Applied Eng. in Agric. 18 (2): 179-182 
22. Penfield, K., B. Young, J. Young, G. Kruger, R. Henry, and G. Lindner, 2015. Physical and biological effects of modified polysorbate 20. In Pesticide Formulation and Delivery Systems: $34^{\text {th }}$ Volume, Translating Basic Science into Products. ASTM International

23. Wang, R., G. Dorr, A. Hewitt, and J. Cooper-White, 2016. Impacts of polymer/surfactant interactions on spray drift. Colloids and surfaces A: Physicochemical and engineering aspects, 500: 88-97
24. Wolf, R. E. 2003. Assessing the ability of DropletScan to analyze spray droplets from a ground operated sprayer. Applied Eng. In Agric. 19 (5): 525-530

25. Zhu, H., M. Salyani, and R.D. Fox, 2011. A portable scanning system for evaluation of spray deposit distribution. Computers and Electronics in Agriculture, 76(1): 38-43. 